\title{
Prominente motiewe in 'n seleksie preke voor, tydens en na die Anglo-Boereoorlog'
}

\author{
C.J.H. Venter \\ Skool vir Kerkwetenskappe (Praktiese Teologie) \\ Potchefstroomse Universiteit vir $\mathrm{CHO}$ \\ POTCHEFSTROOM \\ E-pos: dmscjhv@puknet.puk.ac.za
}

\begin{abstract}
Prominent motifs in a selection of sermons delivered before, during and immediately after the Anglo-Boer War

This article investigates a selection (160) of sermons delivered before, during and after the Anglo-Boer war and published afterwards. The aim of the investigation is to indicate (possible) repetitive motifs used in these sermons. The initial hypothesis taken was that the motif of freedom probably would have functioned prominently within the context of the war. The investigation of the 160 selected sermons, however, proved that although the motif of freedom indeed occurs, it is applied in the broad Biblical sense of being liberated from sin. Freedom in God is stressed and not primarily freedom from British oppression. Several other motifs also function prominently in these sermons - motifs like redemption in Christ, hope, comfort in hardship and peace with God in Jesus Christ. Although these motifs are applied within the context of the Bible, it should be kept in mind that these sermons were delivered in the time of the Anglo-Boer War. These sermons should, therefore, be studied as embedded within a certain time frame: text and context should both be considered in the analysis of these sermons. The analysis, however, indicates that the parts from Scripture selected for these sermons were treated homiletically in a responsible way.
\end{abstract}

1 Erkenning word hiermee gegee aan assistentswerk deur mnr. Hannes Noëth. 


\section{Inleiding}

\subsection{Aktualiteit}

Tans word weer sterk gefokus op die Anglo-Boereoorlog (1899-1902) en talle publikasies oor die oorlog het die afgelope paar jaar verskyn (vergelyk onder andere Kruger (1996); Pretorius (1998) en Scholtz (1998)). Ook oor persone/ helde uit daardie tyd is heelwat geskryf vergelyk byvoorbeeld Barnard (1988); Cameron (1994). Plekke waar veldslae plaasgevind het en beskrywings oor die veldslae is onder andere beskryf deur Van den Bergh (1996) en Oosthuizen (1998). Selfs die menslike ervarings is opnuut nagevors (vgl. Hollenbach (1999); Tempelhoff (1998)) asook die rol wat swart en bruin mense gespeel het in hierdie Vryheidstryd (Wessels, 1998). Resente Afrikaanse romans en kortverhale oor die Anglo-Boereoorlog versterk die fokus op hierdie oorlog (vgl. Baker, 1998; Ferreira, 1998).

Tog is dit 'n leemte dat daar skynbaar weinig navorsing gedoen is oor die rol wat die Woordbediening van die Afrikaanse kerke op die vryheidstryd gehad het.

\subsection{Doel}

Hierdie artikel het ten doel om aandag te gee aan moontlike prominente motiewe wat voorgekom het in preke van predikante van die GKSA rondom die tyd van die Anglo-Boereoorlog. Onder motiewe word verstaan die ondersteunende gedagtes wat deurgaans in die prediking sterk na vore gekom het. Die artikel is nie primêr 'n homileties-eksegetiese beoordeling van die preke uit daardie tyd nie, maar is ' $n$ verkenning van motiewe wat in die prediking in die tyd van die Anglo-Boereoorlog na vore gekom het.

Waarskynlik sou dieselfde gedagtes gevind kon word in die ontleding van preke uit ander tye, byvoorbeeld die Eerste Wêreldoorlog, Tweede Wêreldoorlog en moontlik ook uit preke van 1999. Sekere van die genoemde motiewe het wel universele geldigheid, en sou dus nie noodwendig net aan die genoemde oorlogsjare gekoppel kon word nie. Tog word daar in hierdie artikel, vanweë die aktualiteit daarvan, toegespits op die Anglo-Boereoorlog en word verken in watter opsig die motiewe betrekking gehad het op die mense wat die oorlog ervaar het.

\subsection{Metode vir en agtergrond van die artikel}

Sowat 160 preke wat predikante uit die GKSA gepreek het voor, tydens en na die Anglo-Boereoorlog is bestudeer. Die metode wat gebruik is, is dié van analise en interpretasie, induksie en deduksie. 
Aanvanklik is dié preke bestudeer met die oog daarop om die moontlikheid van vryheid as preekmotief voor, tydens en na die Anglo-Boereoorlog na te gaan. Daar is uitgegaan van die hipotese dat vryheid as motief sterk sou figureer. Gou het dit egter duidelik geword dat dit nie die geval is nie. Vryheid as gedagte waaromheen 'n preek gebou was, was daar, maar nie as oorkoepelende, duidelik uitstaande motief nie. Naas vryheid as motief is ander motiewe wat net so sterk voorgekom het, geïdentifiseer - motiewe wat duidelik ook betrekking gehad het op die ervaringswêreld van mense wat die Anglo-Boereoorlog beleef het. Hierdie motiewe sluit onder andere in rus, stryd, hoop, vryheid (verlossing), vrede en troos.

'n Moontlike antwoord oor hoekom die idee van "vryheid" nie so sterk voorkom soos wat 'n mens sou verwag nie, word waarskynlik gegee deur W.J. Snijman (1904(a):voorwoord) as hy skryf: "Want wij prediken niet ons zelven, maar Christus Jezus, den Heere".

Aanvullend hierby kan gewys word op M. Postma (1904a:571) se woorde: “... op den kansel moet Christus, en Christus alleen verkondigd en Gods Woord verklaard worden". Hy bevestig hierdie uitgangspunt weer (1904a: 582) "De geschiedenis van den oorlog tusschen Engeland en onze beide voormalige Republieken van 1899-1902 moet nog beschreven worden. Wij willen ook niet politiek op den kansel brengen."

Die artikel word soos volg uiteengesit: daar word begin met twee preke waarin 'n hele paar van hierdie motiewe gelyktydig voorkom (en dit word van toepassing gemaak op die konteks van die hoorders), daarna word die motiewe individueel bespreek en word gewys op die prominensie en frekwensie daarvan in preke uit daardie tyd.

\section{Prominente motiewe wat voorkom in preke rondom die tyd van die Anglo-Boereoorlog}

\subsection{Inleidend}

Op 20 Augustus 1899, kort voor die uitbreek van die Anglo-Boereoorlog gebruik Ph. S. Snijman (1904:558) dié woorde tydens 'n verootmoedigingsdiens:

Ernstige en gewichtige dagen zijn voor ons aangebroken, dagen van zorg, angst en kommer, waarin donkere oorlogswolken boven onze hoofden zweven. $\mathrm{O}$, de toekoms is duister.

En ook: 
Onze vijand is machtig. Engelands macht is groot - onze macht is klein. 'Zoo min ik met mijne hand aan den hemel kan vatten, zoo min kunnen wij in eigen kracht tegen Engeland vechten', zeide onze Commandant-Generaal tijdens den vrijheidsoorlog, 'maar ik zie op hooger hand', was zijn geloofstaal. Zoo is het. Engeland is machtig, maar niet almachtig. Dat is God alleen. De harten van Engelands vorsten worden ook door God beheerscht, zijn in Zijne hand gebonden (Ph. S. Snijman, 1904).

Met hierdie woorde in gedagte kan 'n mens verstaan waarom sekere motiewe sterk sal figureer. Die predikers kon nie die konteks waarin hulle preek, ignoreer nie. Dit is interessant om te sien op watter wyse hierdie motiewe in preke aangewend word.

Dat daar na die oorlog steeds bepaalde behoeftes was, word duidelik uit Lion Cachet (1906:voorwoord) waar hy skryf:

De lijken onzer dierbaren liggen verspreid door gansch Zuid-Afrika.

Het land is met steenhoopen bedekt, waaronder de gesneuvelden liggen, bij de kampen zijn de grafplaatsen der vrouwen en kinderen.

Soms vind ' $n$ mens ' $n$ hele paar van hierdie motiewe sterk op die voorgrond in een preek, byvoorbeeld in die twee preke wat hieronder bespreek sal word. Ander kere word een van die motiewe weer so sterk beklemtoon dat die hele preek tematies daarop fokus. In hierdie verband kan byvoorbeeld verwys word na die preek van Maury (1908:89-99) getiteld "De ware vrijheid" waar die saak rondom vryheid en ware vryheid aan die orde kom. Ook kan verwys word na Coetsee (1908(b):27-35) se preek getiteld "Verzekerdheid der hoop" waarin hoop, as sentrale motief, sterk beklemtoon word.

Soms word dit baie duidelik dat die motiewe oorvleuel en dikwels in een paragraaf gebruik word. As voorbeeld kan verwys word na 'n gedeelte uit 'n preek van D. Postma (1899a:8), "Voor den avond":

De morgen brengt zijn nieuwe zorgen en bekommernissen, nieuwen angste en strijd - en daarom gelukkig, ja welgelukzalig de mensch, die door Gods genade na zulk een rust en vredenacht wel toegerust is voor den last en strijd van elke dag!

Let op die woorde stryd, en rus en vrede. In die bestudering van preke uit dié tyd kry 'n mens telkens te doen met genoemde prominente gedagtes en motiewe. 


\subsection{Twee voorbeelde van preke waarin 'n paar van die prominente motiewe gelyktydig figureer}

\subsubsection{P. Postma (1904(a):127-138) - "Aardsche teleurstelling en Goddelijke uitkomst}

In hierdie preek van P. Postma (1904(a):127-138) vind 'n mens minstens vyf van die prominente motiewe, naamlik rus, stryd, hoop, vryheid (verlossing) en troos.

\section{'n Skets van die preek met 'n aanduiding in watter verband som- mige prominente motiewe voorkom}

As teks word Eksodus 17 gebruik met as kernvers Eksodus 17:5, 6 . Hierdie teksgedeelte handel oor die Here se opdrag aan Moses om van die oudstes van Israel te identifiseer en met sy staf op die rots te slaan, sodat die volk kan drink.

Die hoofpunte wat in die preek bespreek word, is die volgende:

- Die beproewing van Moses by Rafidim

- Die heerlike Godsopenbaring in die beproewing en

- die wonderlike verlossing.

\section{- Rus}

P. Postma (1904(a):128) bespreek Rafidim, wat rusplek beteken, en stel dat dit skyn 'n verkeerde benaming te wees as 'n mens kyk na die gebeurtenis wat daar plaasgevind het. Die punt waarby hy (P. Postma, 1904(a):128) wil uitkom, is dat ware rus die rus in God is. Hierdie rus is die middelpunt van die gelowige se verlange; die soeke na hierdie rus is die middelpunt van die gelowige se stryd. (Opvallend is die korrekte wyse waarop die prediker hier met rus en stryd omgaan.) Bogenoemde gedagte bring 'n mens by die tweede prominente motief, naamlik stryd.

\section{- Stryd}

In die rus wat ons in God vind, word ons sorge en moeite van die lewe nie weggeneem nie: op die lewenspad deur God oor ons beskik, is daar baie moeite, teenstand, teleurstelling en uiterlike stryd ( $P$. Postma, 1904(a):128-129).

\section{- Hoop}

Rafidim is 'n rusplek, 'n plek van hoop. Na die dorre woestyn is daar weer hoop. Mans, vrouens en kinders, eers moedeloos, gaan nou voort, op soek na rus. Dan kom die boodskappers - by Rafidim is geen water 
te vind nie. Nou ontwikkel teleurgestelde hoop. Dan begin die stryd vir Moses. Die volk is opstandig. Hulle soek hoop by ander, nie by God nie (P. Postma, 1904(a):134-135).

\section{- Verlossing/vryheid}

Toe Moses moedeloos staan, toon God sy mag. God sê dat Hy voor die aangesig van Moses sal staan. Dis asof Hy sê: vrees nie, Ek is by jou, jou skild. Ek sal soos 'n muur wees rondom jou. God se verlossing is 'n heerlike verlossing (P. Postma, 1904(a):136).

Die verlossing word ook 'n stap verder gevat:

In de duisternis schijnt het heerlijk licht. Dat is de weg der geestelijke verlossing, want de steenrots die volgde was Christus. Denk aan Golgothas kruis, en de ure der duisternis, in welke de Zone Gods moest uitroepen 'Mijn God, Mijn God, waarom hebt Gij Mij verlaten?'. Daar werd het licht in de duisternis (P. Postma, 1904(a):137).

Hierdié benadering belig troos as prominente motief.

\section{- Troos}

P. Postma (1904(a):136, 137) stel dat ook ons ons soveel keer op die menslike verstand beroep: ons redeneer en oorweeg, maar alles word duister en ons roep in nood uit. Maar waar alles vir die mens duister is, skep God 'n nuwe weg. Postma (1904(a):138) verwys dan ook ten slotte na die Psalmdigter wat in angste van die dood en die hel moes uitroep: ek roep tot $U, U$ is my toevlug, sterkte en eer ... (Ps. 142).

\subsubsection{W.J. Snijman (1904(b):276-288) - "De verdrukkingen en smarten van zijn volk voor God niet verborgen"}

Prominente motiewe wat in genoemde preek voorkom, is stryd, troos, verlossing, vrede, en hoop.

\section{Preekskets en aanduiding van prominente motiewe}

As teks word geneem Eksodus 3 met as teksverse vers 7-8a. Hierdie teksgedeelte benadruk die gedagte dat die Here sê dat Hy die verdrukking van sy volk sien, dat Hy hulle hulpkreet vanuit Egipte hoor, en dat Hy bewus is van hulle smarte. Daarom kom Hy nou om hulle te verlos uit Egipte.

Die hoofpunte in die preek is soos volg:

- God sien hulle verdrukking 
- Hy hoor hulle hulpkreet

- Hy ken hulle smarte

- Hy bewerk hulle verlossing (W.J. Snijman, 1904(b):279).

\section{- Stryd}

Die uitverkore volk was in verdrukking in Egipte. Daar het hulle, ten spyte van verdrukking, as volk vermeerder en 'n sterk volk geword. W.J. Snijiman (1904(b):277) skryf in die preek oor die verdrukking: "Waarlijk, Gods uitverkoren volk was in een vurigen oven van verdrukking. En, het was een lange - zeer lange verdrukking!"

In hierdie stryd van verdrukking is daar egter ook 'n bewustheid van die troos-element.

\section{- Troos}

Alles het daarop gedui dat Israel as volk van God verlate was. Tog was hulle verdrukking deel van die onbegryplike raad van God. Die duur en die mate van hulle bittere lyding is alles deur God bepaal.

Toegepas op die situasie waarin sy hoorders hulle bevind, antwoord W.J. Snijman (1904(b):279):

Laat dit uwe troost zijn, verdrukt volk van God, waar er nu zoovele vragen in uw bang gemoed oprijzen. Uw lijden komt van Gods bestel, en Zijne uitverkorenen en liefste kinderen worden minste verschoond van lijden. Zie Hebr. 12. Uw lijden is Hem niet onbekend. Hy heeft tijd en mate ervan bepaald, maar ook het doel en einde.

Later in die preek stel hy (1904(b):281): "Nog eens, hoe troostrijk de gedachte: God ziet het - Mijn Vader ziet het."

\section{- Verlossing/vryheid}

Die verlossing lê vir die volk daarin dat God hulle verdrukking sien. In sy alomteenwoordigheid en alwetendheid het Hy alles aanskou. Daar het niks gebeur wat Hy nie aanskou het nie (W.J. Snijman, 1904(b):279280).

Daar kom dikwels 'n tyd wanneer die volk van God in donkerheid verkeer en geen lig het nie. Maar God sien alles; daarom word die hoorders ook aangemoedig (W.J. Snijman, 1904(b):281) om nooit moedeloos te vra: Sou God dit ooit weet? Hulle word aangemoedig om al die duisend angste en sorge "over uzelf, de kerk, land en volk tot Hem," te bring "die alles ziet en weet ...". 


\section{- Vrede}

Deurdat God alles sien en aanskou, sal Hy op sy tyd, soos deur Hom tevore bepaal, aan dié wat verdruk sê: swyg, wees stil - en in die verdruktes sal daar 'n groot vrede wees (W.J. Snijman, 1904(b):287).

\section{- Hoop}

By die bespreking van hierdie motief kan gesien word hoe die ander motiewe geïnkorporeer word om by hoop uit te kom.

Vir duidelikheid word die ander motiewe wat in hierdie gedeelte voorkom, kursief gedruk:

Hij komt, gij gevangenen des Heeren, die daar hoopt. Hij komt, als uw Redder, gevangenen des doods, die gedurig naar Hem uitziet. Hij komt, gij door onweder voortgedrevene ongetrooste zielen, om u eene eeuwige vertroosting te brengen. En waar de Kerke des Heeren in het laatste der dagen weder in de vreeselijkste verdrukkingen en vervolgingen zal moeten verkeeren, daar zal dit woord: Hij komt! hare kracht en sterkte zijn. Want Zijne komst alleen is het, die haar heil volmaken zal. Hij die zoo dikwijls kwam, om zijn volk te redden, zal eindelijk komen, om het voor eeuwig vrij te maken van alle smart en pijn, van alle moeite en verdriet, van satan, zonde en dood, opdat er eeuwige blijdschap op zijn hoofd moge zijn. Is deze God ook Uw God, mijne hoorders? Of behoort gij nog tot degenen, die zijn volk smaden en verdrukken? Indien nog het laatste, dan is het voor u een vreeselijk woord: Hij komt! Want Hij komt niet alleen, om Zijn volk te verlossen, maar om ook Zijn volk te wreken. Hoe vreeslijk is het afgeloopen met Farao en zijn volk, toen de Heere tot Egypte gekomen was. En gij, geloovigen, wacht op den Heere, ja wacht en hoopt op Zijn woord. Hij zal het voor u maken (W.J. Snijman, 1904(b):288).

\subsection{Samevattend}

Uit bogenoemde voorbeelde is dit duidelik dat die geïdentifiseerde prominente motiewe duidelik ook gerig was op die mense van hulle tyd vergelyk veral W.J. Snijman (1904) se toepassings op die "verdrukte volk". Krities sou daar gevra kan word of die Afrikaner se situasie nie oordrewe gelykgestel word aan Israel se verdrukking nie?

Gelykstelling van die Afrikaner met die uitverkore nasie Israel was 'n probleem wat telkens in die prediking opgeduik het (vgl. M. Postma (1904(a):568-589 se "Rede bij het vernemene van her overlijden van Z.H.Ed. Paul Kruger" waar 'n mens 'n byna direkte gelykstelling kry tussen Paul Kruger en Moses.) Met hierdie aspek in gedagte sou 'n mens 
kon vra of W.J. Snijman (1904) die "verdrukte volk" (Afrikaners) nie te eksemplaristies vergelyk met die "verdrukte volk" (Israel) nie?

Soos bogenoemde twee preke sou ook nog gekyk kon word na P. Postma (1904(b):150-159) se preek "De zekerheid van het genadeverbond" waarin die motiewe stryd, hoop, troos, en vrede voorkom; en Coetsee (1908:11-18) se "De roepstem tot vermoeiden" waarin 'n mens die motiewe van stryd, vryheid, rus en troos kan onderskei.

\section{3. 'n Bespreking van die prominente motiewe}

\subsection{Inleidend}

Soos duidelik geblyk het uit die behandelde voorbeelde word die motiewe dikwels in 'n vervlegte verband gebruik. Uit die preke wat bestudeer is, het dit ook duidelik geword dat die motiewe mekaar soms aanvul, uitbrei, of in mekaar ingebed is. Daarom is dit nie moontlik om 'n vaste orde aan te dui of om die perspektiewe van belangrik na minder belangrik te evalueer of rubriseer nie. Tog, soos uit die bespreking hieronder aangedui sal word, kry 'n mens meestal dat die gedagte van stryd vooropstaan, gevolg deur die gedagte van die soeke na rus en vrede. Die vind van rus en vrede dien as troos. Vanuit die troos word hoop gebied wat gefundeer is in die ware vryheid/verlossing in God.

Met die oog hierop word die motiewe ook nader behandel in die volgorde, naamlik stryd, rus, vrede, troos, hoop, vryheid/verlossing.

\subsection{Stryd}

Uit die bestudeerde preke is dit duidelik dat stryd vanuit verskillende hoeke benader is.

\section{- Menslike stryd}

Van die menslike stryd waarin die hoorders hulle tans (in oorlogstyd) bevind, skryf Ph. S. Snijman (1904:558): "De tijd, dien wij heden doorleven, is geen tijd van lachen en van vreugde, maar een tijd van weenen en bedroefd te zijn".

Hoe sterk hierdie stryd deel van 'n mens se lewe is, word treffend uitgedruk in 'n preek "Verlos uw volk" van Van Rooy (1904:219) as hy skryf:

De drie bondgenooten tegen Christus gemeente zijn sterk, te weten: satan, de wereld en eigen vleesch - de list des Boozen, de gelijkvormigheid aan de wereld en de natuurlijke neigingen van eigen hart. Leugen, geweld, begeerlijkheid, zietdaar de drie machtige 
bondgenooten, die in ons land en onder ons volk ook de Kerk des Heeren hebben bestormd, tot een diepen val gebracht en in meewarigen toestand gelaten.

Let dan veral op sy woorde (Van Rooy, 1904:219) met betrekking tot die Vryheidsoorlog:

Vernieling, verwoesting is niet slechts daarbuiten aan huizen en landerijen aangericht; niet alleen is verlies geleden aan goed en bloed. Nee, ook hier binne, in 't hart van Jerusalem, in 't Huis des Heeren, in 't geestelijke Zion, de gemeente Christi, hebben de vijanden onzer ziel geroofd en gemoord. Hoe is de zonde losgebroken! Hoe is de Naam des Heeren onteerd, de Heilige Geest bedroefd geworden!

Weereens sou hier gevra kon word of die prediker nie die gelykstelling te ver neem deur die Boerevolk en die "hart van Jerusalem", met mekaar gelyk te stel nie?

\section{- Geestelike stryd}

Teenoor die stryd wat die mens hier voer, is daar ook die geestelike stryd. Hiervan sê Lion Cachet (1904:38) in een van sy preke:

$\mathrm{Er}$ is een strijden tegen de zonde, een pogen om het hart te verniewen, dat moedeloos, ja wanhopig maak. Men zoekt zichzelven te bekeeren, en niets is er dat de ziel meer kwelt. Gij weet dit misschien bij ondervinding. Elken morgen wordt de strijd begonnen en elken avond moet men erkennen dat men een nederlaag gelede heeft. Men begint elke jaar met de schoonste voornemens, en op elken oudejaarsavond is dezelfde klaagtoon op de lippen.

Pelser (1908:67) sluit sterk hierby aan met die woorde:

Neen, waar een Christen zich dan ook bevind in die woestijn van deze wereld, en hij een woestijn reiziger is, daar is strijd ... Die strijd is tegen zwarigheden van allerlei aard, tegen sterke en machtige vijanden.

Die oorsaak en gevolge van hierdie stryd het ook in die preke aandag geniet. Hier kan verwys word na W. Postma (1904:339) in sy preek "De klacht der beproefden" waarin hy dit duidelik stel dat die stryd smart en kleingeloof bring. Postma (1904:339) sê:

Toen die vreeselijke oorlog als een zwaar onweder over ons losbarstte, en tegensoed op tegenspoed volgde. Toen wij eindelijk op het open veld, in verre eilande, in die nooit te vergeten kampe, maandenlang moesten kwijnen, wat waren toen onze gedacthen? 
Wat zeiden wij toen niet menigmaal in de bitterheid onzer smart? Wie heeft niet menigmaal onder al die beproevingen het Jakob nagezegd: 'Alle deze dingen zijn tegen mij'.

Die menslike stryd is ook in die oorlogstyd gebruik om die mense te waarsku om tot inkeer te kom oor hulle sondes en om diepe berou te hê. So het Ph. S. Snijman (1904:562-563) duidelik aan sy hoorders gestel dat God in beheer is van ons stryd, en die volk kan dit duidelik sien in die oorlogstyd. Volgens Ph. S. Snijman (1904:562-563) het die volk Engeland as tugroede. Hy (1904:562-563) vestig die toehoorders se aandag op die geskiedenis van ons volk en land: wanneer die volk se beker van ongeregtigheid vol is, sal die waterstrome aankom om die oordeel oor die volk te voltrek. In die preek word gestel dat God Engeland as gésel gebruik om die gelowige daarmee te tug. Volgens hierdie preek kan die roede tot genesing bydra.

Hierdie gedagte van stryd stimuleer egter die begeerte na rus en vrede.

\subsection{Rus}

In hierdie verband stel Coetsee (1908a:15) dat ten spyte van die stryd waarin die mens homself bevind, God beloof dat Hy rus sal gee.

Hierdie rus word direk gekoppel aan die stryd wat dit voorafgaan, asook aan die feit dat Christus die stryd stry en sodoende rus gee. So stel Snijman dit (1899(b):30):

$U$ strijd tegen Satan is Zijne strijd, en Hij zal den Satan haast onder uwe voeten verpletteren ... Geef door geloof alles aan Hem over, en gij zult rust vinden voor uwe vermoeide ziel.

Aan die mense wat hulle in hierdie vryheidstryd bevind het, word dus duidelik gestel: "God wil den armen zondaar helpen, om tot de ware zielerust en vrede te komen" (Snijman, 1899(a):18). Hierdie beloofde rus word ook aangedui as nie net aardse rus nie, maar ewige rus wat reeds begin met die oomblik van bekering:

Deze rust, geliefde, begint reeds van af het oogenblik dat de zondaar wederkeert tot zijn verlosser, maar zij word sterker en grooter wanneer de zondaar Jezus heeft gevonden. Dan gaat hij voort van kracht tot kracht, totdat hij hiernamaals de rust in volmaaktheid zal genieten. Welk eene bemoediging voor vermoeide, voor zoekende zielen. Het is eene bemoediging zoo lieflijk, zoo heerlijk, zoo troostrijk, dat zij onze dubbele aandacht ten allen tijde waardig is. Het is zeker een van de schoonste woorden, die Jezus gesproken heeft. 'Kom herwaarts tot Mij, allen die vermoeid en belast zijt, en Ik zal u ruste geven' (Coetsee, 1908(a):16). 


\subsection{Vrede}

Dat vrede in hierdie tyd ' $n$ belangrike motief was, is heel verstaanbaar. In die prediking is die motief van vrede op meervoudige wyse aangewend. Alhoewel 'n mens kan aanvaar dat "vrede op aarde" die begeerte van die hoorders sou wees, word baie klem gelê op vrede in Christus. Hierdie vrede gee rus en verseker vryheid. W. Postma (1904:335) stel dit duidelik dat geloof in God selfs in die donkerste ure van beproewing vrede sal gee:

Och, dat wij vasthielden aan dat geloof in den God Jakobs, ook in de duisterste uren van beproeving en strijd, dan zouden wij vrede hebben in het hart, troost in onze smarten, dan zouden wij nimmer beschaamd behoeven te staan, maar wij zouden dan met recht kinderlijk geloof onzen Vader die in de hemelen is, verheerlijken.

D. Postma (1893(b):151) stel dit onomwonde dat om hierdie vrede te bring die rede is vir Christus se koms na die wêreld:

Hooren wij de engelen niet zeggen, om vrede te brengen op aarde, namelijk rede voor den verloren, mensch? o, Ja gewis! en nu vrage een iegelijk zichzelven eens af of hij dezen vrede al deelachtig is; want zonder denzelven te bezitten kan geen mensch zalig worden.

Hy (D. Postma, 1893(b):151-155) brei uit oor hierdie vrede en roep dan sy hoorders op deur die volgende gedagte te beklemtoon: $U$ moet dink aan die vrede van God - die vrede wat Christus gebring het. $U$ is nou versoen met Christus. Christus het immers vir u vrede gemaak by God. $U$ het reeds vrede by Christus en God sal dit bewaar. Verheug $u$ en wees bly, want die Here het vrede beskik deur die bloed aan die kruis (154-155).

In die bewuswording van die stryd is daar die begeerte na rus en vrede. Die vind hiervan dien as troos. Daarom is troos ook ' $n$ prominente motief in preke van hierdie tyd.

\subsection{Troos}

Om die hoorders te troos in die tyd waarin hulle verkeer, was 'n verdere belangrike aspek van die prediking. So is "Onze hulpe in den Heere" 'n preek van W.J. Snijman (1899(a):19), getuienis daarvan. Hy (1899(a):19) stel dit pertinent in sy preek "Wij hebben hier een onpeilbaar oceaan van troost".

In 'n preek getiteld "Eene troostvolle bemoediging voor Gods kerk" troos D. Postma (1893(c):308) sy luisteraars met dié woorde: "Wat Gods 
gemeente hier op aarde ook nog hebbe door te staan, hetzij haar genoeg tot waarborg te hebben: God is met ons!"

Hy sluit hierdie preek oor "troostvolle bemoediging" dan af met die woorde (1893(c):312): "Houdt dus goeden moed, kinderen Gods! in alle verdrukking."

Die toehoorders word getroos met die wete dat God die (geestelike) stryd saam met hulle stry. Hy ken hulle smart en die moeilike stryd van die geloof. Die troos lê vir die uitverkorenes daarin dat God hulle geestelik en liggaamlik bystaan (M. Postma, 1904(b):257). So word ook duidelik gestel dat die Here die geloof in gelowiges se harte bewerkstellig deur die kragtige werking van die Heilige Gees, om Christus ontwil, tot 'n ryke troos in al ons lyde en stryd in die lewe (W. Postma, 1904:340).

Ph. S. Snijman (1904:558) vat die troosgedagte treffend saam: "Doch wat troost geeft is de gedachte: God regeert en $\mathrm{Hij}$ is genadig en barmhartig." Die troos wat voortvloei uit die rus en vrede in God skep uiteindelik hoop.

\subsection{Hoop}

Dat hoop as prominente motief figureer, word duidelik deur byvoorbeeld te verwys na twee preke waarin hoop die preektema is, naamlik "Verzekerdheid der hoop" van Coetsee (1908(b):27-35) en Ph. S. Snijman (1908:161-170) se "De hoop des Christens".

In eersgenoemde preek word aandag gegee aan die sekerheid wat die hoop op Christus bring. So word dit gestel:

In alles verdrukt, doch niet benauwd; twijfelmoedig, docht niet mismoedig; vervolg, doch niet verlaten; nedergebogen, doch niet verworpen, neen, in alles overwinnaar door Jezus Christus, onzen Heere!

Van waar de blijdschap? Van waar die moed? Vanwaar die kracht? Uit ons? Neen, zij kunnen niet uit ons zijn. Er is nabij den Christen een onzictbare zon, die hem bestraalt, eene onzichtbare hand, die hem onderschraagt, eene onzichtbare mond, die hem toespreekt; eene onzichtbare Geest, die zich woning in zijn hart maakt (Coetsee, 1908(b):33).

Die sekerheid van die hoop lê hierin: "My verlosser leef!" (Coetsee, 1908(b): 34). 
In die preek van Ph. S. Snijman (1908:161-170) maak hy dit duidelik dat die lot van die Christen in die wêreld is om moeilikhede en verdrukkinge te ondergaan. Tog word die Christen vermaan om nie in droefheid en treurigheid te verval nie, maar om goeie moed te hou (te hoop?). Hy stel in die preek dat verdrukking lydsaamheid wek, lydsaamheid wek ervaring en ervaring wek hoop - hoop wat nie beskaam nie. Die gelowige weet dat God ten spyte van verdrukking uitkoms sal gee. Die hoop bestaan dat die genade van God die gelowige in die toekoms nie sal onthou word nie. Die hoop beskaam nie. Die gelowige sal nie bedroë daarvan afkom nie. Die hoop van die gelowige is die anker van die siel. Die aksent wat op hoop geplaas is, is gefundeer in die vryheid/verlossing van Christus.

\subsection{Vryheid/verlossing}

Die motiewe van vryheid en verlossing is deurgaans saam gebruik op grond van die feit dat die hoop gebou word op die gedagte van vryheid. Hierdie vryheid soos dit in die preke na vore kom, gaan nie soseer oor aardse vryheid nie, maar oor die "hoogste vryheid". Vryheid in Christus en verlossing deur Christus is dus die fondament van die voorafgaande hoop. Ten spyte van verdrukking, omstandighede en stryd is daar vryheid en verlossing in en deur Christus.

In die tyd tussen die Eerste Vryheidsoorlog (1881) en die Anglo-Boereoorlog, tydens die veertiende verjaarsdag van die Teologiese Skool, 24 November 1883, preek D. Postma (1893(a):37) oor die "groote beginsel!". Hy sê hieroor:

Dat groote beginsel was bij Luther, Zwingli, en Calvijn niet wijsgeerig, maar gemoedelijk, door persoonlijke overtuiging, naar verkrege inzicht, zonder afspraak, zonder onderling verband, en nochtans in geheele overeenstemming in: 'het groote beginsel'.

Hierdie groot beginsel waarna hy verwys, is die vryheid in Christus soos dit gevind word in Galasiërs 5:1.

Waaroor die ware vryheid gaan, omlyn Van Rooy (1904:220) vir die mens in die vryheidstryd as hy skryf: Verlos van ongeregtigheid: dit, geliefdes, sal eenmaal die heerlike vryheid van God se kinders wees. Vrygemaak van sonde. Hy (Christus) het deur stryd oorwin en leef tot in ewigheid (Van Rooy, 1904:227-vertaald). Hier kan positief opgemerk word dat Van Rooy (1904) die ware vryheid suiwer gesien het, sonder om in die slaggat te trap en 'n valse "volks"-vryheid aan die toehoorders voor te hou.

Nieteenstaande bogenoemde word 'n mens tog bewus van die feit dat "aardse vryheid" nie maklik net "weggedink" is as slegs die "vryheid in 
Christus" nie. So kan verwys word na M. Postma (1904(a) se woorde in die "Rede bij het vernemen van het overlijden van Z.H.Ed. Paul Kruger":

Hij (verwysende na Paul Kruger) was overtuigd, dat ons volk door God geroepen was om den zuiveren godsdienst voort te planten en eenmaal een vrij, zelfstandige en onafhankelijk volk te worden ...

Hij geloofde, zijn volk moet blijven bestaan als een zelfstandig, onafhankelijk volk en hij wilde zijn volk dienen, niet eene vreemde regeering. Daarvoor leefde, daarvoor stierf hij ... Hij geloofde, en wij gelooven het ook, dat God ons volk bestemd heeft tot een zelfstandig, vrij en onafhankelijk volk, en dat Hij, naar zij eeuwig raadsbesluit op zijnen tijd het zal vrij maken (M. Postma, 1904(a): $578,581)$.

Maury (1908:89-99) trek die onderskeid tussen aardse vryheid en hemelse vryheid nog sterker deur in sy preek "De ware vrijheid":

En waar het verlangen naar vrijheid nog steeds woont in het hart des menschen; waar ook in onze dagen zoo vele banden knellen en doen zuchten, zoo vele ellenden drukken, zooveel verdriet aan het harte knaagt, zal dan de herinnering aan Israels heerlijk feest der bevrijding geen andere snaar in ons harte doen trillen, dan die van weemoed, omdat die gelukkige tidjen nooit weer uit het grijze verlede zullen opdagen?"(92)

Maury dui aan dat die teksvers kom met 'n groter vryheid, naamlik die vryheid in Jesus Christus. Dit is 'n vryheid wat nie verlore kan gaan nie, maar wat duur tot in ewigheid (93). Dit is die ware vryheid.

Hy $(1908: 96,98)$ sê verder oor hierdie vryheid dat "[d]e waarde dezer vrijheid in Christus is onschatbaar. Deze vrijheid is met niets op aarde te vergelijken". Werklik vry is om deur Christus vrygemaak te wees: "Eeuwige en volmaakte vrijheid door Christus verworven".

Ook ten opsigte van die beklemtoning in hierdie preek sou 'n mens kon opmerk dat die prediker die saak van vryheid baie suiwer en reg gesien het.

\section{Slot}

Die volgende konkluderende opmerkings kan gemaak word oor die prominente motiewe uit 'n seleksie preke in die tyd rondom die AngloBoereoorlog:

- Prediking in die tyd van die Anglo-Boereoorlog was gerigte prediking. Hiervan is die geïdentifiseerde motiewe 'n duidelike bewys. Die preke 
was gefokus op die mense in die vryheidstryd en is daadwerklik toegepas op die situasie van die hoorders.

- Stryd as preekmotief het duidelik 'n prominente rol gespeel in die prediking asook in die belangrike onderskeid tussen menslike stryd en geestelike stryd.

- Die gedagte van stryd het die begeerte na rus en vrede gestimuleer. Ook hieraan is in die prediking aandag gegee. Aan die mense in die vryheidstryd is duidelik gestel dat God hulle wil lei tot sielerus en vrede. Die rus is nie aangedui as ' $n$ aardse rus nie: die vrede met Christus is as die vrede aangedui wat ware vryheid na vore bring.

- Voorts is die hoorders getroos met die gedagte dat God regeer en dat Hy die groot Trooster is. Dié troos het hoop tot gevolg gehad en die hoop was gefundeer in die vryheid/verlossing van Christus.

- Aardse vryheid (dit wil sê vryheid van die Engelse) was as sodanig nie 'n primêre motief van die prediking nie. Vryheid in Christus as ware vryheid is baie sterker beklemtoon.

- Krities sou gevra kon word of die Afrikanervolk en Israel se verdrukking nie in sommige preke te sterk met mekaar gelykgestel is nie?

Die bestudering van hierdie preke het dit dus duidelik gemaak dat in die prediking teks en konteks nie geskei kan word nie. Die boodskap van die evangelie is tydloos en tog bepaal spesifieke omstandighede die fokus en impak van die gepredikte Woord.

\section{Bibliografie}

BAKER, E. 1998. Groot duiwels dood. Human \& Rousseau : Kaapstad.

BARNARD, C.J. 1988. Die vyf swemmers. Kaapstad: Tafelberg.

CAMERON, T. 1994. Jan Smuts - An illustrated biography. Kaapstad : Human \& Rousseau.

COETSEE, M.P.A. snr. 1908(a). De roepstem tot vermoeiden. (In Erfenis en nalatenschap: zijnde 29 leerredenen, uitgesproken door verschillende predikanten van de Geref. Kerk van Zuid-Afrika met voorwoord van ds. L.P. Vorster. Burgersdorp : "De Stem" Drukkerij. p.11-18.)

COETSEE, M.P.A. snr. 1908(b). Verzekerdheid der hoop. (In Erfenis en nalatenschap: zijnde 29 leerredenen, uitgesproken door verschillende predikanten van de Geref. Kerk van Zuid-Afrika met voorwoord van ds. L.P. Vorster. Burgersdorp : "De Stem" Drukkerij. p. 27-35.)

FERREIRA, Jeanette. 1998. Boereoorlogstories. Pretoria : Van Schaik.

HOLLENBACH, C.A. 1999. Briewe uit die Boereoorlog. Floridapark : Driefontein Publikasies. 
KRUGER, R. 1996. Goodbye Dolly Gray - The Story of the Boer War. London : Random House.

LION CACHET, J. 1904. Nieuwjaar. (In Bewaar het pand u toebetrouwd: Drie en vijftig leerredenen over verscheidene stoffen. Pretoria : Höveker \& Wormser. p. 32-41.)

LION CACHET, J. 1906. Voorwoord. (In De Klerk, W.J. De gesneuvelden en gestorvenen van de Gereformeerde Kerken in Zuid-Afrika gedurende den oorlog 1899-1902. Pretoria : Van der Reyden. Voorwoord.)

MAURY, J.L. 1908. De ware vrijheid. (In Erfenis en nalatenschap: zijnde 29 leerredenen, uitgesproken door verschillende predikanten van de Geref. Kerk van Zuid-Afrika met voorwoord van ds. L.P. Vorster. Burgersdorp : "De Stem" Drukkerij. p. 89-99.)

OOSTHUIZEN, A.V. (samesteller). 1998. A guide to the battlefields, graves and monuments of the Anglo-Boer War in the North Eastern Cape. Bloemfontein : Die Oorlogsmuseum vir die Boererepublieke.

PELSER, M. 1908. De overwinning en hare vruchtgevolgen. (In Erfenis en nalatenschap: zijnde 29 leerredenen, uitgesproken door verschillende predikanten van de Geref. Kerk van Zuid-Afrika met voorwoord van ds. L.P. Vorster. Burgersdorp : "De Stem" Drukkerij. p. 65-72.)

POSTMA, D. snr. 1893(a). Gal. 5:1 - Het groote beginsel der Hervorming in het begin der zestiende eeuw. (In Postma, D. jnr. Eenige nagelatene leerredenen van wijlen prof. D. Postma. Kaapstad : Argus Maatschappij Beperk. p. 37-38.)

POSTMA, D. snr. 1893(b). Luk. 2:13, 14 - De lofzang der engelen. (In Postma, D. jnr. Eenige nagelatene leerredenen van wijlen prof. D. Postma. Kaapstad : Argus Maatschappij Beperk. p. 144-155.)

POSTMA, D. snr. 1893(c). Openb. 1:17c en 18 - Eene troostvolle bemoediging voor Gods Kerk. (In Postma, D. jnr. Eenige nagelatene leerredenen van wijlen prof. D. Postma. Kaapstad : Argus Maatschappij Beperk. p. 308-312.)

POSTMA, D. jnr. 1899(a). Voor den avond. (In Postma, D. Een dertigtal leerredenen. Preto-ria : Höveker \& Wormser. p. 1-10.)

POSTMA, D. jnr. 1899(b). De liefde Gods een onberouwelijke liefde. (In Postma, D. Een dertigtal leerredenen. Pretoria : Höveker \& Wormser. p. 151-159.)

POSTMA, M. 1904(a). Rede bij het vernemen van het overlijden van Z.H.Ed. Paul Kruger. (In Bewaar het pand u toebetrouwd: Drie en vijftig leerredenen over verscheidene stoffen. Pretoria : Höveker \& Wormser. p. 568-589.)

POSTMA, M. 1904(b). De uitverkiezing Gods (predestinatie) de vaste grond, het vaste fondament van de zaligheid der uitverkorenen. (In Bewaar het pand u toebetrouwd: Drie en vijftig leerredenen over verscheidene stoffen. Pretoria : Höveker \& Wormser. p. 245-263.)

POSTMA, P. 1904(a). Aardsche teleurstelling en goddelijke uitkomst. (In Bewaar het pand $\mathrm{u}$ toebetrouwd: Drie en vijftig leerredenen over verscheidene stoffen. Pretoria : Höveker \& Wormser. p. 127-138.)

POSTMA, P. 1904(b). De zekerheid van het Genade-verbond. (In Bewaar het pand u toebetrouwd: Drie en vijftig leerredenen over verscheidene stoffen. Pretoria : Höveker \& Wormser. p. 150-159.)

POSTMA, W. 1904. De klacht der beproefden. (In Bewaar het pand u toebetrouwd: Drie en vijftig leerredenen over verscheidene stoffen. Pretoria : Höveker \& Wormser. p. 334-340.)

PRETORIUS, F. 1998. Die Anglo-Boereoorlog 1899-1902. Kaapstad : Struik.

SCHOLTZ, G.D. 1998. Die Anglo-Boereoorlog 1899-1902. Pretoria : Protea Boekhuis. 
SNIJMAN, Ph. S. 1904. Dag van verootmoediging en gebed. Leerrede uitgesproken den 20en Augustus 1899. (In Bewaar het pand u toebetrouwd: Drie en vijftig leerredenen over verscheidene stoffen. Pretoria : Höveker \& Wormser. p. 557567.)

SNIJMAN, Ph. S. 1908. De hoop des Christens. (In Erfenis en nalatenschap: zijnde 29 leerredenen, uitgesproken door verschillende predikanten van de Geref. Kerk van Zuid-Afrika met voorwoord van ds. L.P. Vorster. Burgersdorp : "De Stem" Drukkerij. p. 161-170.)

SNIJMAN, W.J. 1899(a). Onze hulpe in den Heere. (In Snijman, W.J. Is het wel met u? Vijf en twintig preeken. Pretoria : Höveker \& Wormser. p. 12-21.)

SNIJMAN, W.J. 1899(b). Daniëls geloof niet beschaamd. (In Snijman, W.J. Is het wel met u? Vifj en twintig preeken. Pretoria : Höveker \& Wormser. p. 22-30.)

SNIJMAN, W.J. 1904(a). Voorrede. (In Bewaar het pand u toebetrouwd: Drie en vijftig leerredenen over verscheidene stoffen. Pretoria : Höveker \& Wormser. p. voorwoord.)

SNIJMAN, W.J. 1904(b). De verdrukkingen en smarten van zijn volk voor God niet verborgen. (In Bewaar het pand u toebetrouwd: Drie en vijttig leerredenen over verscheidene stoffen. Pretoria : Höveker \& Wormser. p. 276-288.)

TEMPELHOFF. J.W.N. red. 1998. Images of War in Vereeniging - T.N. Leslie's "Letters to Jane"1899-1901. Vereeniging : Tempelhoff \& the Vaal Teknorama.

VAN DEN BERGH, G. 1996. 24 Veldslae en slagvelde van die Noordwes Provinsie. Potchefstroom : Die Noordwes Toerisme Assosiasie.

VAN ROOY, J.A. 1904. Verlos uw volk. (In Bewaar het pand u toebetrouwd: Drie en vijftig leerredenen over verscheidene stoffen. Pretoria : Höveker \& Wormser. p. 216-227.)

WESSELS, A. 1998. Die militêre rol van swart mense, bruin mense en Indiërs tydens die Anglo-Boereoorlog (1899-1902). Bloemfontein : Die Oorlogsmuseum van die Boererepublieke.

\section{Kernbegrippe:}

gerigte prediking

hoop

motief van vryheid

prominente preekmotiewe

teks en konteks

troos in teëslae

vryheidstryd

\section{Key concepts:}

comfort in hardships

focused preaching

freedom struggle

hope

motif of freedom

prominent motifs in sermons

text and context 